\title{
Resilience of soil functions to transient and persistent stresses is improved more by residue incorporation than the activity of earthworms
}

Article

Accepted Version

Creative Commons: Attribution-Noncommercial-No Derivative Works 4.0

Shu, X., Hallett, P. D., Liu, M., Baggs, E. M., Hu, F. and Griffiths, B. S. (2019) Resilience of soil functions to transient and persistent stresses is improved more by residue incorporation than the activity of earthworms. Applied Soil Ecology, 139. pp. 10-14. ISSN 0929-1393 doi: https://doi.org/10.1016/j.apsoil.2019.03.008 Available at https://centaur.reading.ac.uk/82712/

It is advisable to refer to the publisher's version if you intend to cite from the work. See Guidance on citing.

To link to this article DOI: http://dx.doi.org/10.1016/j.apsoil.2019.03.008

Publisher: Elsevier

All outputs in CentAUR are protected by Intellectual Property Rights law, including copyright law. Copyright and IPR is retained by the creators or other copyright holders. Terms and conditions for use of this material are defined in the End User Agreement. 


\section{www.reading.ac.uk/centaur}

\section{CentAUR}

Central Archive at the University of Reading

Reading's research outputs online 


\section{Resilience of soil functions to transient and persistent stresses is improved}

2 more by residue incorporation than the activity of earthworms

3 Xin Shu ${ }^{1,2,3 *}$, Paul D. Hallett ${ }^{3}$, Manqiang Liu ${ }^{4}$, Elizabeth M. Baggs ${ }^{5}$, Feng $\mathrm{Hu}^{4}$, Bryan S.

$4 \quad$ Griffiths $^{2}$

$5{ }^{1}$ Department of Geography and Environmental Science, University of Reading, RG6 $6 D W$,

$6 U K$

$7 \quad{ }^{2}$ Crop and Soil Systems Research Group, SRUC, Edinburgh, EH9 3JG, UK

$8 \quad{ }^{3}$ School of Biological Sciences, University of Aberdeen, Aberdeen, AB24 3UU, UK

$9{ }^{4}$ Soil Ecology Lab, College of Resources and Environmental Sciences, Nanjing Agricultural

10 University, Nanjing, 210095, China

$11{ }^{5}$ The Royal (Dick) School of Veterinary Studies, University of Edinburgh, Easter Bush

12 Campus Buildings, Midlothian, EH25 9RG, UK

13 Corresponding authror email: x.shu@reading.ac.uk

\section{Abstract}

15 The development of soil sustainability is linked to the improved management of soil biota, 16 such as earthworms, and crop residues to improve soil physical structure, enhance microbial 17 activities, and increase nutrient cycling. This study examined the impacts of maize residue $18\left(65.8 \mathrm{C} / \mathrm{N}\right.$ ratio, dry biomass $\left.0.75 \mathrm{~kg} \mathrm{~m}^{-2}\right)$ incorporation and earthworms (70 $\mathrm{g}$ Metaphire 19 guillelmi $\mathrm{m}^{-2}$ ) on the resistance and resilience of soil $\mathrm{C}$ and $\mathrm{N}$ cycling to experimentally 20 applied stresses. Field treatments were maize residue incorporation, maize residue 21 incorporation with earthworm addition, and an unamended control. Resistance and resilience 22 of C mineralization, ammonia oxidation, and potential denitrification were investigated over 2328 days following a persistent stress of $\mathrm{Cu}\left(1 \mathrm{mg} \mathrm{Cu}\right.$ soil g $\left.{ }^{-1}\right)$ or a transient heat stress $\left(50{ }^{\circ} \mathrm{C}\right.$ 24 for 16 hours). The results indicated that $\mathrm{C}$ mineralization was more resistant and resilient than 25 ammonia oxidation and denitrification to either a persistent $\mathrm{Cu}$ or a transient heat stress. The 
application of maize residues significantly increased soil microbial biomass, $\mathrm{C}$ mineralization,

27 ammonia oxidation and potential denitrification compared with the unamended control. Maize

28 residues significantly improved the resistance and resilience of $\mathrm{N}$ processes to $\mathrm{Cu}$ and heat

29 stress. The presence of earthworms significantly increased potential denitrification but had

30 limited positive effect on functional resistance and resilience. This study suggested crop

31 residue incorporation would strongly increase soil functional resistance and resilience to

32 persistent and transient stresses, and thus could be a useful agricultural practice to improve

33 soil ecosystem sustainability.

34 Keywords: crop residue, soil fauna, C mineralization, ammonia oxidation, denitrification

\section{1. Introduction}

36 Increasing soil degradation has raised awareness of soil sustainability of which a central

37 component is the capability to withstand (resistance) and recover (resilience) from

38 environmental stresses (Griffiths and Philippot, 2013). So much so that a global resilience

39 programme in response to land use pressures has been suggested (Smith et al., 2016). Soil

40 microorganisms play a central role in conferring resistance and resilience, through their

41 central role within the soil food web and sensitivity to agricultural practices (de Vries and

42 Shade, 2013). Crop residue amendment would increase soil organic matter (SOM), the

43 decomposition of which provides nutrients and energy to support the growth and succession

44 of soil biota (Shade et al., 2012). Increased SOM also leads to improved soil physical

45 properties (Diacono and Montemurro, 2010), and accelerated carbon (C) and nitrogen (N)

46 cycling (Turmel et al., 2015). Thus, SOM may be an important resource to strengthen the

47 resistance and resilience of soil ecosystem (Lal, 2015).

48 Improving the management of soil biota, such as earthworms, in agroecosystem is an integral

49 part of sustainable management (Fonte and Six, 2010) especially as biotic interactions of the

50 soil food web are a critical determinant of soil function, including resistance and resilience (de 
51 Vries and Wallenstein, 2017). Of the three ecological groups of earthworms: anecics build a

52 relatively permanent vertical burrow system and feed on organic matter collected from the

53 soil surface, epigeics live and feed within the soil matrix creating horizontal burrows, and

54 endogeics inhabit the surface layers of soil consuming fresh organic matter (Brussaard et al.,

55 2012). To varying extents earthworms mix organic matter into the soil, influence soil

56 aggregation and porosity (Fonte and Six, 2010), gas diffusion and soil water retention, and

57 soil microbial community structure (Bernard et al., 2012). The availability and composition of

58 substrate provided by crop residues affects earthworm diet, behaviour and growth (Brussaard

59 et al., 2012; Zheng et al., 2018). Experiments have shown that the interaction between

60 earthworms and plant residues affects soil functions. Thus, earthworms regulated the ratio of

61 C- to $\mathrm{N}$ - degrading enzyme activities during crop residue decomposition in a laboratory

62 experiment (Zheng et al., 2018). Aspects of the interaction between added crop residues and

63 earthworms have also been explored in a long-term field trial of a wheat-rice cropping system

64 in sub-tropical China (Tao et al., 2009). Results showed that the presence of earthworms

65 further enhanced protease and alkaline phosphatase activities in soil with incorporated maize

66 residue (Tao et al., 2009). A comparison of bacterial community structure in the same field

67 trial (Gong et al., 2018), showed that residue incorporation had significant effects on bacterial

68 community structure and that earthworms increased the ratio of Proteobacteria to

69 Acidobacteria (indicative of high nutrient turnover). Earthworms also increased the

70 connection between taxa, which is taken as an indicator of compositional resilience (Dunne et

71 al., 2002). The interaction between plant cover and earthworms on soil resistance and

72 resilience was explored in a short-term greenhouse experiment, which revealed that plants

73 rather than earthworms increased resistance and resilience to soil compaction (Griffiths et al.,

74 2008). 
75 To further explore such interactions, we used samples from a long-term field experiment to

76 determine whether amendments with maize residues and earthworms affected the functional

77 resistance and resilience of soil. We quantified changes in $\mathrm{C}$ mineralization, ammonia

78 oxidation and potential denitrification rates immediately after heat- (short-term transient) and

$79 \mathrm{Cu}$ - (long-term persistent) induced stress and during subsequent recovery over 28 days after

80 Griffiths et al. (2001). Because of the identified effects of earthworms and maize residues to

81 alter microbial community composition and increase $\mathrm{C}$ and $\mathrm{N}$ cycling in the field experiment

82 (Gong et al., 2018), we hypothesised that soil amended with maize residues and earthworms

83 would have greater resistance and resilience than soil amended with maize residues alone.

\section{2. Materials and methods}

\section{$85 \quad 2.1$ Study site and soil samples}

86 A field trial at the experimental station of Nanjing Agricultural University (China, $118^{\circ} 47^{\prime} \mathrm{E}$, 87 and $32^{\circ} 03^{\prime} \mathrm{N}$ ) was established in 2001. In each plot, there were three treatments as described 88 by Tao et al. (2009): maize residues (Zea mays L.) incorporated into soil, maize residues incorporated into soil with earthworm (Metaphire guillelmi) addition, and a control with no additions. Each treatment had three replicate plots, arranged in a completely randomized

91 experimental design. Earthworms were monitored after every harvesting stage annually and 92 were added if necessary to maintain a density of $70 \mathrm{~g}$ earthworm $\mathrm{m}^{-2}$. This earthworm is the 93 dominant species in this area, commonly found in disturbed arable soil and its behaviour 94 shows it to be endogeic (Gong et al., 2018). Maize residues $\left(0.75 \mathrm{~kg} \mathrm{~m}^{-2}\right.$ air-dry weight, 95 chopped $<2 \mathrm{~cm}$ ) containing $7.96 \mathrm{~g} \mathrm{~N} \mathrm{~kg}^{-1}, 2.85 \mathrm{~g} \mathrm{P} \mathrm{kg}^{-1}, 10.67 \mathrm{~g} \mathrm{~K} \mathrm{~kg}^{-1}$, and $65.8 \mathrm{C} / \mathrm{N}$ ratio 96 were applied to the appropriate plots at the beginning at rice and wheat growth period every 97 year.

98 The soil, classified as an Orthic Acrisol, was sampled in May 2016. From each plot, three 99 surface soil samples $(0-20 \mathrm{~cm}$ depth) approximately $10 \mathrm{~kg}$ in weight were randomly sampled 
and mixed thoroughly. The soil had a $\mathrm{pH}\left(\mathrm{H}_{2} \mathrm{O}\right)$ of 8.25 and contained $5.86 \mathrm{~g} \mathrm{C} \mathrm{kg}^{-1}$ and 0.71

$101 \mathrm{~g} \mathrm{~N} \mathrm{~kg}^{-1}$ soil (Shu, 2018). Soil microbial biomass carbon (MBC) was analysed by chloroform

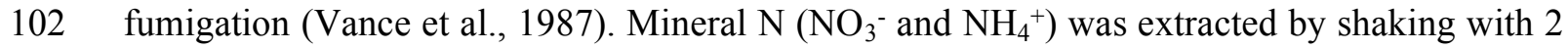

$103 \mathrm{M} \mathrm{KCl}$ for 1 hour and analysed using a continuous flow analyser (Skalar San++ 4800,

104 Netherlands). Dissolved organic carbon (DOC) was extracted following the method of Ghani

105 et al. (2003) and analysed using a TOC analyser (Dohrmann DC-80, UK).

$106 \quad 2.2$ Resistance and resilience assay

107 Soils from all the treatments were packed to a bulk density of $1.1 \mathrm{~g} \mathrm{~cm}^{-3}$ and incubated for 7 108 days with a water content of $60 \%$ water-filled pore space (WFPS) at $20{ }^{\circ} \mathrm{C}$ prior to analysis.

109 The stresses imposed followed Griffiths et al. (2001) and were: $\mathrm{Cu}\left(1 \mathrm{mg} \mathrm{Cu}\right.$ soil g $\left.\mathrm{g}^{-1}\right)$ to 110 provide a persistent stress; and heat $\left(50{ }^{\circ} \mathrm{C}\right.$ for 16 hours $)$ to provide a transient stress. For the 111 heat stressed soil, a preliminary test (Supplementary material 1) indicated that the temperature 112 of $40{ }^{\circ} \mathrm{C}$ that has been typically applied in studies on temperate soils (Griffiths et al., 2001)

113 was not a sufficient stress for these subtropical soils because of their great adaptation to a 114 relatively high temperature (Table S1), as also found by Zhang et al. (2010). For each soil, 115 aliquots were exposed to either a stress (heat or $\mathrm{Cu}$ ) or were unstressed as a control, with six 116 replicates for each field treatment and laboratory applied stress. Each aliquot contained $220 \mathrm{~g}$ 117 dry-weight equivalent of soil (bulk density $1.1 \mathrm{~g} \mathrm{~cm}^{-3}$ ) in a $500 \mathrm{ml}$ capacity polypropylene pot.

118 Six replicate aliquots of each stressed- soil were prepared by adding $2.2 \mathrm{ml}$ of $1.57 \mathrm{M}$ $119 \mathrm{CuSO}_{4} \cdot 5 \mathrm{H}_{2} \mathrm{O}$ to obtain a concentration of $1 \mathrm{mg} \mathrm{Cu}$ soil g-1 ; or $2.2 \mathrm{ml}$ of sterile distilled water 120 to both the heat-stressed and unstressed (control) soils. All the aliquots were then sealed with 121 parafilm to exchange air but prevent any water loss. The heat- stressed soils were then 122 incubated at $50{ }^{\circ} \mathrm{C}$ for 16 hours, while both $\mathrm{Cu}$-stressed and unstressed soil were incubated at $12320{ }^{\circ} \mathrm{C}$ for 16 hours. All aliquots were then incubated at $20{ }^{\circ} \mathrm{C}$ for the remainder of the 124 resilience assay. 
125 To facilitate temporal description, day 0 was defined as the time when $\mathrm{Cu}$ or heat was applied.

126 Subsamples were taken for the analysis of microbial functions at intervals of 1, 3, 7, 14 and

12728 days after the stresses were imposed. C mineralization was measured by the emission of

$128 \mathrm{CO}_{2}$ after 24 hours following the addition of $120 \mu \mathrm{l}$ of organic $\mathrm{C}$ compounds which provides

$12950 \mathrm{mg} \mathrm{C} \mathrm{ml}^{-1}$ and $9.72 \mathrm{mg} \mathrm{N} \mathrm{ml}^{-1}$ to a $2 \mathrm{~g}$ of soil (Shu, 2018). Ammonia oxidation was

130 determined by the chlorate inhibition method (Groffman 1985). Potential denitrification was

131 determined following anaerobic incubation of $20 \mathrm{~g}$ soil in the presence of $10 \%(\mathrm{v} / \mathrm{v})$ acetylene

132 (Shu, 2018).

\section{$133 \quad 2.3$ Data analysis}

134 A linear mixed effect model was fit in the "lme4" package for the "R" statistical programme 135 (version 3.5.2) using the "Imer" function (Bates et al., 2019). Effects of fixed term and 136 random term on $\mathrm{C}$ mineralization, ammonia oxidation and potential denitrification were 137 analysed. Fixed terms were field treatment, stress, time, and their interaction (treatment $\times$ 138 stress $\times$ time). The replicate plot was considered a random term.

139 Stability $f(t)$ was calculated as the change in biological functions of the stressed soil $(\beta)$ 140 compared with the unstressed control $(\alpha)$ at day $t$ (Equation 1) (Zhang et al., 2010):

$$
f(t)=\frac{\beta_{t}}{\alpha_{t}} \times 100
$$

141 Resistance was defined as the stability measured at day 1 after perturbation (Equation 2),

142 while resilience was estimated as the integrative stability after day 1 up to 28 days following 143 stress (Equation 3) (Shu, 2018).

$$
\begin{gathered}
\text { Resistance }=\frac{\beta_{1}}{\alpha_{1}} \times 100 \\
\text { Resilience }=\int_{1}^{28} f(t) d t /(28-1)
\end{gathered}
$$


145 Maize residue incorporation significantly increased the concentrations of dissolved organic C 146 and microbial biomass $\mathrm{C}$ (Table 1). The linear mixed effect model demonstrated that maize 147 residue incorporation significantly $(P<0.001)$ increased $\mathrm{C}$ mineralization, ammonia 148 oxidation and denitrification (Table S3). These results are consistent with previous studies 149 that maize residue addition increased microbial biomass $\mathrm{C}$ (Tao et al., 2009) and promoted C 150 sequestration (Shu et al., 2015). An increased supply of nutrients, such as from the maize 151 residues, can hasten microbial growth (Henderson et al., 2010), sustain microorganisms and 152 enhance microbial activities (Shade et al., 2012).

153 When soil was stressed by either $\mathrm{Cu}$ or heat, $\mathrm{C}$ mineralization in all the treatments was more 154 resistant and resilient than ammonia oxidation and potential denitrification (Table 2). This is 155 consistent with several studies which demonstrated that $\mathrm{N}$ processes are more susceptible to 156 external stresses than C processes (Bissett et al., 2013; Morillas et al., 2015). This may be 157 because the microbial community carrying out $\mathrm{C}$ mineralization is more diverse and more 158 functionally redundant than specialized microbial populations performing ammonia oxidation 159 and denitrification (Philippot et al., 2013). Denitrification was particularly susceptible to the 160 applied stresses, with resistance and resilience often less than $20 \%$ (Table 2), as also 161 previously was shown for both $\mathrm{Cu}$ (Magalhães et al., 2007) and heat (Wertz et al., 2007).

162 We found that maize residue incorporation significantly $(P<0.05)$ increased the resistance 163 and resilience of ammonia oxidation and potential denitrification to $\mathrm{Cu}$ (Table 2). This could 164 be attributed to the enhanced microbial biomass (Table 1), as well as the buffering effects by 165 adsorption or chelation of $\mathrm{Cu}^{2+}$ by organic matter which diminishes the bioavailability and 166 toxicity of $\mathrm{Cu}$ to microorganisms (Degryse et al., 2009). The bioavailability of $\mathrm{Cu}$ in soil with 167 incorporated crop residue was likely to be significantly less than in the unamended soil one 168 day after $\mathrm{Cu}$ addition (Navel et al., 2010). Crop residues serve as an energy and nutrient 169 source for microorganisms to accelerate microbial community succession and so increase 
microbial biomass (Brandt et al., 2010). Access to a favourable resource is important for the

171 degree of recovery and the time that microorganisms take to recover (Placella et al., 2012).

172 That organic amendments improved soil functional resistance and resilience to $\mathrm{Cu}$ has been

173 reported previously for C mineralization in temperate soils (Gregory et al., 2009). In contrast,

174 we observed that crop residue incorporation in this soil decreased resistance and resilience of

$175 \mathrm{C}$ mineralization to $\mathrm{Cu}$ (Table 2). We saw that $\mathrm{C}$ mineralization in soil with incorporated crop

176 residue decreased significantly after 3 days incubation in both the unstressed and the $\mathrm{Cu}$

177 stressed soil (Table S2). This could be related to the depletion of available nutrients. The

178 different impacts of residue on the resistance and resilience of $\mathrm{C}$ and $\mathrm{N}$ processes could also

179 be ascribed to the different stress-sensitivity and distinct microbial characteristics between $\mathrm{C}$

180 and $\mathrm{N}$ processes.

181 All the measured microbial functions were resilient to heat, especially ammonia oxidation and 182 potential denitrification in the soil with incorporated maize residue (Table 2). Heat leads to 183 the death of heat-sensitive microorganisms, such as proteobacteria which had a low resistance 184 to heat stress (Frenk et al., 2017). In recovering from a transient heat stress, the attributes of 185 the microbial communities, mixtrophy and intrinsic growth rate, determine microbial use of 186 available $\mathrm{C}$ to reproduce and recolonize niches rapidly (Shade et al., 2012). Necromass, such 187 as dead microbial cells induced by the heat stress, also provides a rapidly mineralised 188 substrate that is easily accessible to free-living microorganisms (Drigo et al., 2012). A 189 previous study has demonstrated that bacterial communities could recover to its original 190 structure from a transient heat stress, but not from a persistent $\mathrm{Cu}$ stress (Shu, 2018). Routine 191 successional trajectories of microbial communities may be altered differently by different 192 stresses (de Vries and Shade, 2013), and gradual shifts of microbial community may be the 193 result of long-term adaptations to the persistent $\mathrm{Cu}$ stress. 
194 In the soils with incorporated maize residues, earthworms significantly increased potential

195 denitrification (Table S3). Earthworms gut, casts and drilospheres are hotspots of

196 denitrification, and thus contribute to high emission of $\mathrm{N}_{2} \mathrm{O}$ (Lubbers et al., 2013). However,

197 earthworm presence had few significant additional impacts on C mineralization and ammonia

198 oxidation (Table S3). The different response between soil functions to earthworms unveils

199 that their underlying microorganisms may be influenced by earthworms differently. For

200 example, in a northern temperate forest in USA, earthworms enhanced cellulolytic enzyme

201 activity and shifted soil microbial composition away from fungi and towards bacteria

202 (Dempsey et al., 2013). Previous studies, at the site where soils were collected for this

203 experiment, demonstrated that earthworms significantly changed the composition and

204 connectance of the microbial community (Gong et al., 2018) and soil enzyme activities (Tao

205 et al., 2009) when maize residues were incorporated. The lack of significant earthworm effect

206 on resistance and resilience in this experiment, suggests that these changes were not enough to

207 affect the stability of the soil. The effects of earthworms may also be overwhelmed by

208 residues, further study should include a treatment of earthworms alone without residue

209 amendment. The small effect of earthworms could result if not all the measured soils had

210 transited through the earthworm gut, because microorganisms and their activities can be

211 stimulated by earthworm mucus (Bernard et al., 2012). This study only focused on the bulk

212 soil, however, Gong and colleagues (unpublished data) have found a significant effect of

213 earthworms on the microbial community associated with soil aggregates. Therefore, it would

214 be interesting to explore how soil resistance and resilience changes at an aggregate scale.

215 In conclusion, $\mathrm{C}$ and $\mathrm{N}$ processes responded differently to imposed stresses, so it is important

216 that assays of resilience explore multiple functions and potential disturbances. Soil functions

217 are less likely to recover from a persistent stress (e.g. $\mathrm{Cu}$ ) than a transient stress (e.g. heat),

218 but transient stresses can still result in a prolonged degradation to soil functions. Stresses 
associated with climate change, such as the frequency of long hot periods, drought or flooding could affect soil for a period after the stresses are removed. The important role of earthworms

221 in ecosystems is widely recognised, however, in this example of a disturbed agricultural soil 222 crop residue addition as a management option was more important than having earthworms 223 present for restoring soil resistance and resilience. Although further research is required 224 across a wider range of soils and with more types of residues, our findings suggest that applying crop residues to a degraded agricultural soil is a primary driver in the recovery of functions like $\mathrm{C}$ and $\mathrm{N}$ cycling that underpin productivity and sustainability.

\section{Acknowledgements}

This work was supported by the Scottish Government Rural and Environment, Science and

Analytical Services Division, the National Key R\&D program (2016YFD0200305), and the

Natural Science Foundation of China (41771287 and 41671255). We thank Shuai Wang, John

Parker and Yufeng Deng for their help with field and laboratory work.

\section{References}

233 Bates, D., Maechler, M., Bolker, B., Walker, S., Christensen, R.H.B., Singmann, H., Bai, B., Scheipl,

234 F., Grothendieck, G., Green, P., Fox, J., 2019. Linear Mixed-Effects Models using "Eigen” and

235 S4. R package version 1. 1-20.

236 Bernard, L., Chapuis-Lardy, L., Razafimbelo, T., Razafindrakoto, M., Pablo, A.L., Legname, E., 237 Poulain, J., Brüls, T., O’Donohue, M., Brauman, A., Chotte, J.L., Blanchart, E., 2012. Endogeic 238 earthworms shape bacterial functional communities and affect organic matter mineralization in a 239 tropical soil. ISME J. 6, 213-222. https://doi.org/10.1038/ismej.2011.87

240 Bissett, A., Brown, M.V., Siciliano, S.D., Thrall, P.H., 2013. Microbial community responses to 241 anthropogenically induced environmental change: towards a systems approach. Ecol. Lett. 16, 242 128-39. https://doi.org/10.1111/ele.12109

243 Brandt, K.K., Frandsen, R.J.N., Holm, P.E., Nybroe, O., 2010. Development of pollution-induced 244 community tolerance is linked to structural and functional resilience of a soil bacterial 
community following a five-year field exposure to copper. Soil Biol. Biochem. 42, 748-757. https://doi.org/10.1016/j.soilbio.2010.01.008

Brussaard, L., Aanen, D.K., Briones, M.J.I., Decaëns, T., De Deyn, G.B., Fayle, T.M., James, S.W., 248 Nobre, T., 2012. Biogeography and phylogenetic community structure of soil invertebrate ecosystem engineers: global to local patterns, implications for ecosystem functioning and services and global environmental change impacts, in: Soil Ecology and Ecosystem Services.

de Vries, F.T., Wallenstein, M.D., 2017. Below-ground connections underlying above-ground food Oxford University, Oxford, pp. 202-232.

de Vries, F.T., Shade, A., 2013. Controls on soil microbial community stability under climate change. Front. Microbiol. 4, 1-16. https://doi.org/10.3389/fmicb.2013.00265 production: a framework for optimising ecological connections in the rhizosphere. J. Ecol. 105, 913-920. https://doi.org/10.1111/1365-2745.12783

Degryse, F., Smolders, E., Parker, D.R., 2009. Partitioning of metals (Cd, Co, Cu, Ni, Pb, Zn) in soils: concepts, methodologies, prediction and applications - a review. Eur. J. Soil Sci. 60, 590-612. https://doi.org/10.1111/j.1365-2389.2009.01142.x

Dempsey, M.A., Fisk, M.C., Yavitt, J.B., Fahey, T.J., Balser, T.C., 2013. Exotic earthworms alter soil microbial community composition and function. Soil Biol. Biochem. 67, 263-270. https://doi.org/10.1016/j.soilbio.2013.09.009

Diacono, M., Montemurro, F., 2010. Long-term effects of organic amendments on soil fertility. A review. Agron. Sustainable Dev. 30, 401-422. https://doi.org/10.1051/agro/2009040

Drigo, B., Anderson, I.C., Kannangara, G.S.K., Cairney, J.W.G., Johnson, D., 2012. Rapid incorporation of carbon from ectomycorrhizal mycelial necromass into soil fungal communities. Soil Biol. Biochem. 49, 4-10. https://doi.org/10.1016/J.SOILBIO.2012.02.003

Dunne, J.A., Williams, R.J., Martinez, N.D., 2002. Network structure and biodiversity loss in food webs: robustness increases with connectance. Ecol. Lett. 5, 558-567. https://doi.org/10.1046/j.1461-0248.2002.00354.x

Fonte, S.J., Six, J., 2010. Earthworms and litter management contributions to ecosystem services in a tropical agroforestry system. Ecol. Appl. 20, 1061-1073. https://doi.org/10.1890/09-0795.1 
Frenk, S., Hadar, Y., Minz, D., 2017. Quality of irrigation water affects soil functionality and bacterial community stability in response to heat disturbance. Appl. Environ. Microbiol. 84. https://doi.org/10.1128/AEM.02087-17

Ghani, A., Dexter, M., Perrott, K.W., 2003. Hot-water extractable carbon in soils: a sensitive measurement for determining impacts of fertilisation, grazing and cultivation. Soil Biol. Biochem. 35, 1231-1243. https://doi.org/10.1016/S0038-0717(03)00186-X

Gong, X., Jiang, Y., Zheng, Y., Chen, X., Li, H., Hu, F., Liu, M., Scheu, S., 2018. Earthworms differentially modify the microbiome of arable soils varying in residue management. Soil Biol. Biochem. 121, 120-129. https://doi.org/10.1016/j.soilbio.2018.03.011

Gregory, A.S., Watts, C.W., Griffiths, B.S., Hallett, P.D., Kuan, H.L., Whitmore, A.P., 2009. The effect of long-term soil management on the physical and biological resilience of a range of arable and grassland soils in England. Geoderma 153, 172-185. https://doi.org/10.1016/j.geoderma.2009.08.002

Griffiths, B.S., Bonkowski, M., Roy, J., Ritz, K., 2001. Functional stability, substrate utilisation and biological indicators of soils following environmental impacts. Appl. Soil Ecol. 16, 49-61. https://doi.org/10.1016/S0929-1393(00)00081-0

Griffiths, B.S., Liu, Q., Wang, H., Kuan, H.L., Mckenzie, B.M., Hallett, P.D., Neilson, R., Daniell, T.J., 2008. Restoration of soil physical and biological stability are not coupled in response to plants and earthworms. Restor. Ecol. 26, 102-104.

Griffiths, B.S., Philippot, L., 2013. Insights into the resistance and resilience of the soil microbial community. FEMS Microbiol. Rev. 37, 112-29. https://doi.org/10.1111/j.15746976.2012.00343.x

Groffman, P.M., 1985. Nitrification and denitrification in conventional and no-tillage soils. Soil Sci. Soc. Am. J. 49, 329-334. https://doi.org/10.2136/sssaj1985.03615995004900020011x

Henderson, S.L., Dandie, C.E., Patten, C.L., Zebarth, B.J., Burton, D.L., Trevors, J.T., Goyer, C., 2010. Changes in denitrifier abundance, denitrification gene mRNA levels, nitrous oxide emissions, and denitrification in anoxic soil microcosms amended with glucose and plant residues. Appl. Environ. Microbiol. 76, 2155-2164. https://doi.org/10.1128/AEM.02993-09 
Lal, R., 2015. Restoring soil quality to mitigate soil degradation. Sustainability 7, 5875-5895. https://doi.org/10.3390/su7055875

Lubbers, I.M., van Groenigen, K.J., Fonte, S.J., Six, J., Brussaard, L., van Groenigen, J.W., 2013.

Shade, A., Peter, H., Allison, S.D., Baho, D.L., Berga, M., Bürgmann, H., Huber, D.H., Langenheder, Placella, S.A., Brodie, E.L., Firestone, M.K., 2012. Rainfall-induced carbon dioxide pulses result from sequential resuscitation of phylogenetically clustered microbial groups. Proc. Natl. Acad. Sci. 109, 10931-10936. https://doi.org/10.1073/pnas.1204306109

S., Lennon, J.T., Martiny, J.B.H., Matulich, K.L., Schmidt, T.M., Handelsman, J., 2012. Fundamentals of microbial community resistance and resilience. Front. Microbiol. 3, 1-19. https://doi.org/10.3389/fmicb.2012.00417

Shu, X., 2018. The mechanisms underlying the resistance and resilience of soil carbon and nitrogen cycling to environmental stresses (Doctoral thesis). University of Aberdeen.

Shu, X., Zhu, A., Zhang, J., Yang, W., Xin, X., Zhang, X., 2015. Changes in soil organic carbon and 
aggregate stability after conversion to conservation tillage for seven years in the Huang-Huai-Hai Plain of China. J. Integr. Agric. 14, 1202-1211. https://doi.org/10.1016/S2095-3119(14)60862-5

331 Smith, P., House, J.I., Bustamante, M., Sobocká, J., Harper, R., Pan, G., West, P.C., Clark, J.M., 332 Adhya, T., Rumpel, C., Paustian, K., Kuikman, P., Cotrufo, M.F., Elliott, J.A., Mcdowell, R., 333 Griffiths, R.I., Asakawa, S., Bondeau, A., Jain, A.K., Meersmans, J., Pugh, T.A.M., 2016. Global

Wertz, S., Degrange, V., Prosser, J.I., Poly, F., Commeaux, C., Guillaumaud, N., Le Roux, X., 2007. Decline of soil microbial diversity does not influence the resistance and resilience of key soil microbial functional groups following a model disturbance. Environ. Microbiol. 9, 2211-2219. https://doi.org/10.1111/j.1462-2920.2007.01335.x

Zhang, B., Deng, H., Wang, H., Yin, R., Hallett, P.D., Griffiths, B.S., Daniell, T.J., 2010. Does microbial habitat or community structure drive the functional stability of microbes to stresses following re-vegetation of a severely degraded soil? Soil Biol. Biochem. 42, 850-859. https://doi.org/10.1016/j.soilbio.2010.02.004

Zheng, Y., Wang, S., Bonkowski, M., Chen, X., Griffiths, B., Hu, F., Liu, M., 2018. Litter chemistry influences earthworm effects on soil carbon loss and microbial carbon acquisition. Soil Biol. Biochem. 123, 105-114. https://doi.org/10.1016/j.soilbio.2018.05.012 


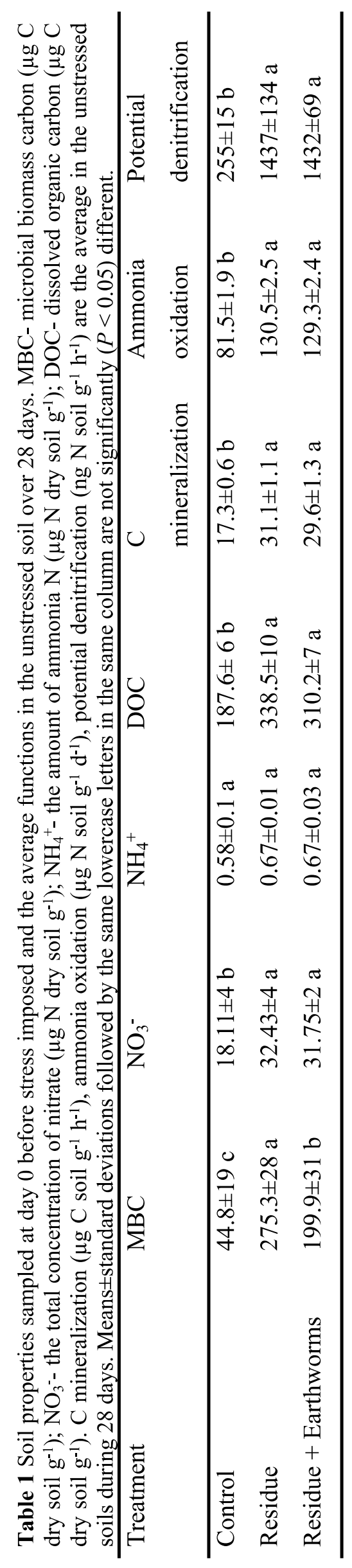




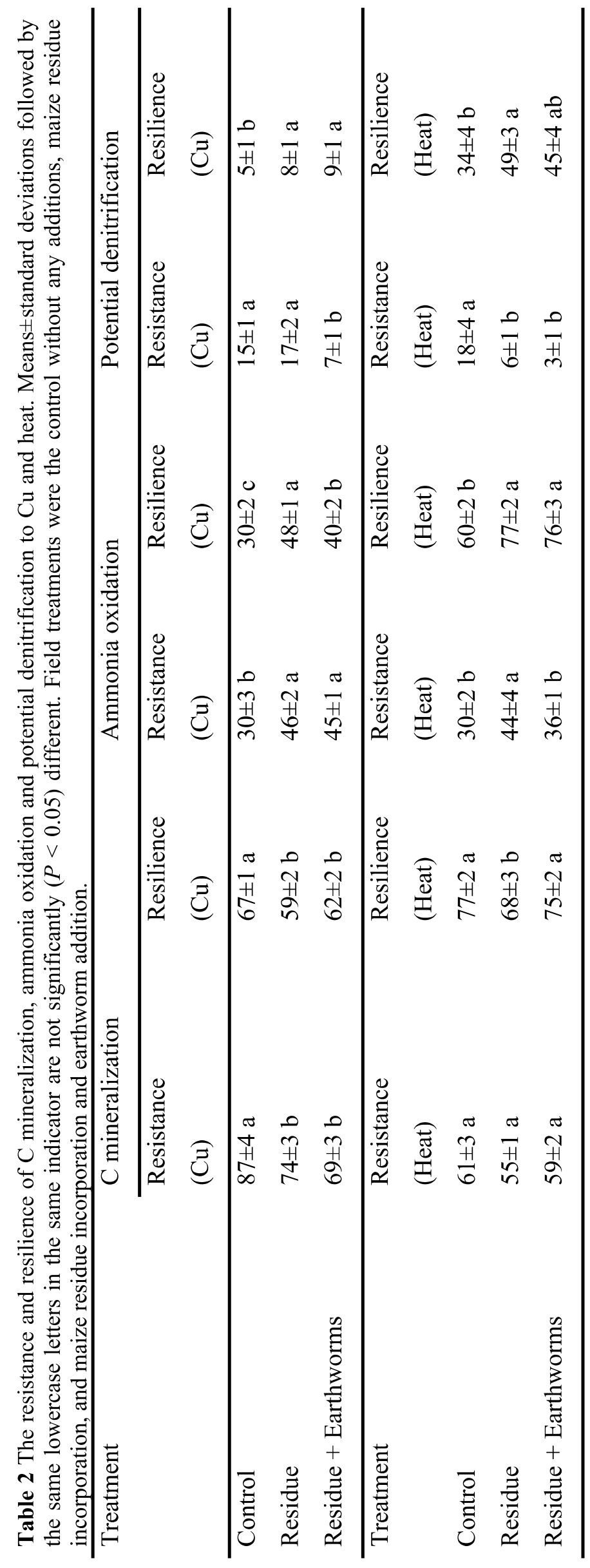




\section{SUPPLEMENTARY MATERIALS}

Resilience of soil functions to transient and persistent stresses is improved more by residue incorporation than the activity of earthworms

Xin Shu ${ }^{1,2,3 *}$, Paul D. Hallett ${ }^{3}$, Manqiang $\mathrm{Liu}^{4}$, Elizabeth M. Baggs ${ }^{5}$, Feng $\mathrm{Hu}^{4}$, Bryan S. Griffiths $^{2}$

\section{Supplementary material 1: Preliminary Experiment}

Soils from the treatments of control and maize residue incorporated and earthworm added were packed to a bulk density of $1.1 \mathrm{~g} \mathrm{~cm}^{-3}$, and incubated for 7 days with a water content of $60 \%$ water-filled pore space (WFPS) at $20^{\circ} \mathrm{C}$ prior to the preliminary test. For each soil, aliquots were exposed to either a stress (heat at $40{ }^{\circ} \mathrm{C}$ or $50{ }^{\circ} \mathrm{C}$ ) or were unstressed as a control, with three replicates for each treatment and stress. Each aliquot contained $220 \mathrm{~g}$ dry-weight equivalent of soil in a $500 \mathrm{ml}$ capacity pot. Three replicate aliquots of each stressed- soil were prepared by adding $2.2 \mathrm{ml}$ of sterile distilled water to both the heat-stressed and unstressed control soils. All aliquots were then sealed with parafilm to exchange air but prevent any water loss. The heat- stressed soils were then incubated at either 40 or $50{ }^{\circ} \mathrm{C}$ for 16 hours, while the unstressed soils were incubated in a moist atmosphere at $20^{\circ} \mathrm{C}$ for 16 hours. All aliquots were then incubated at $20^{\circ} \mathrm{C}$ for the remainder of the same resilience assay. C mineralization, ammonia oxidation and potential denitrification were measured over 7 days following stress. The methods of $\mathrm{C}$ mineralization, ammonia oxidation and potential denitrification are described in main text. 


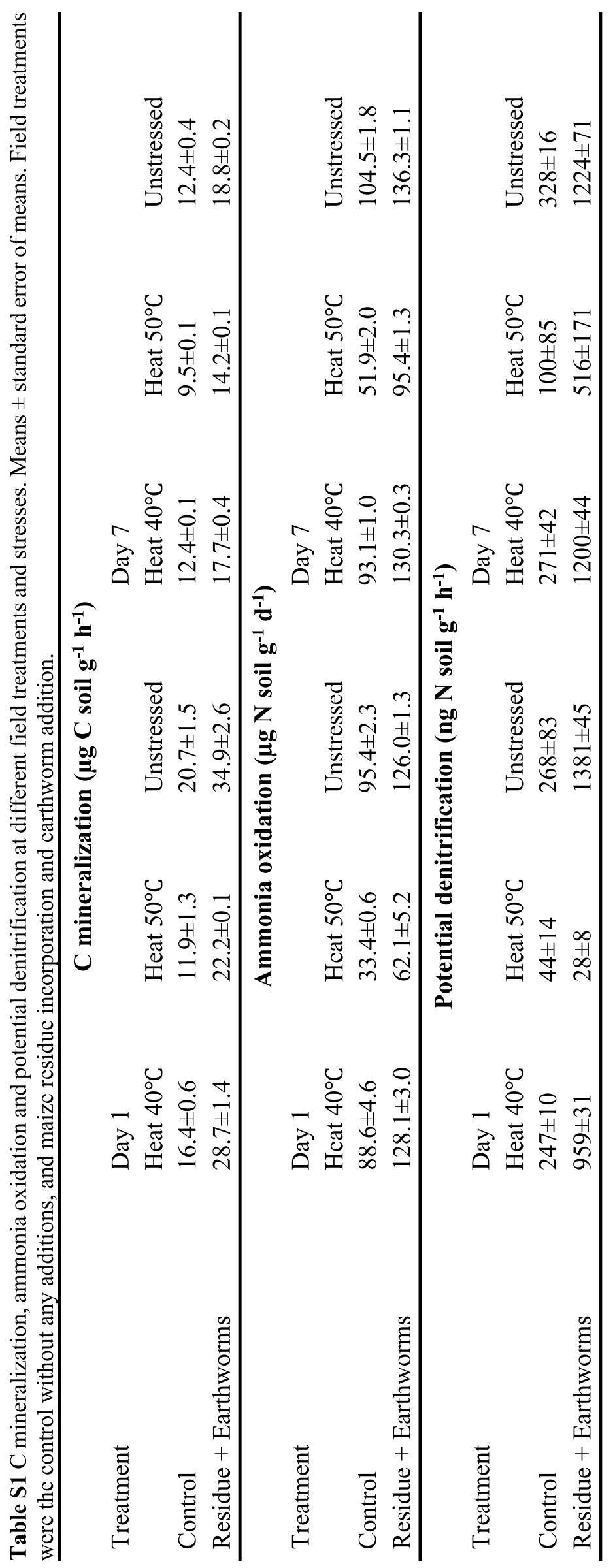




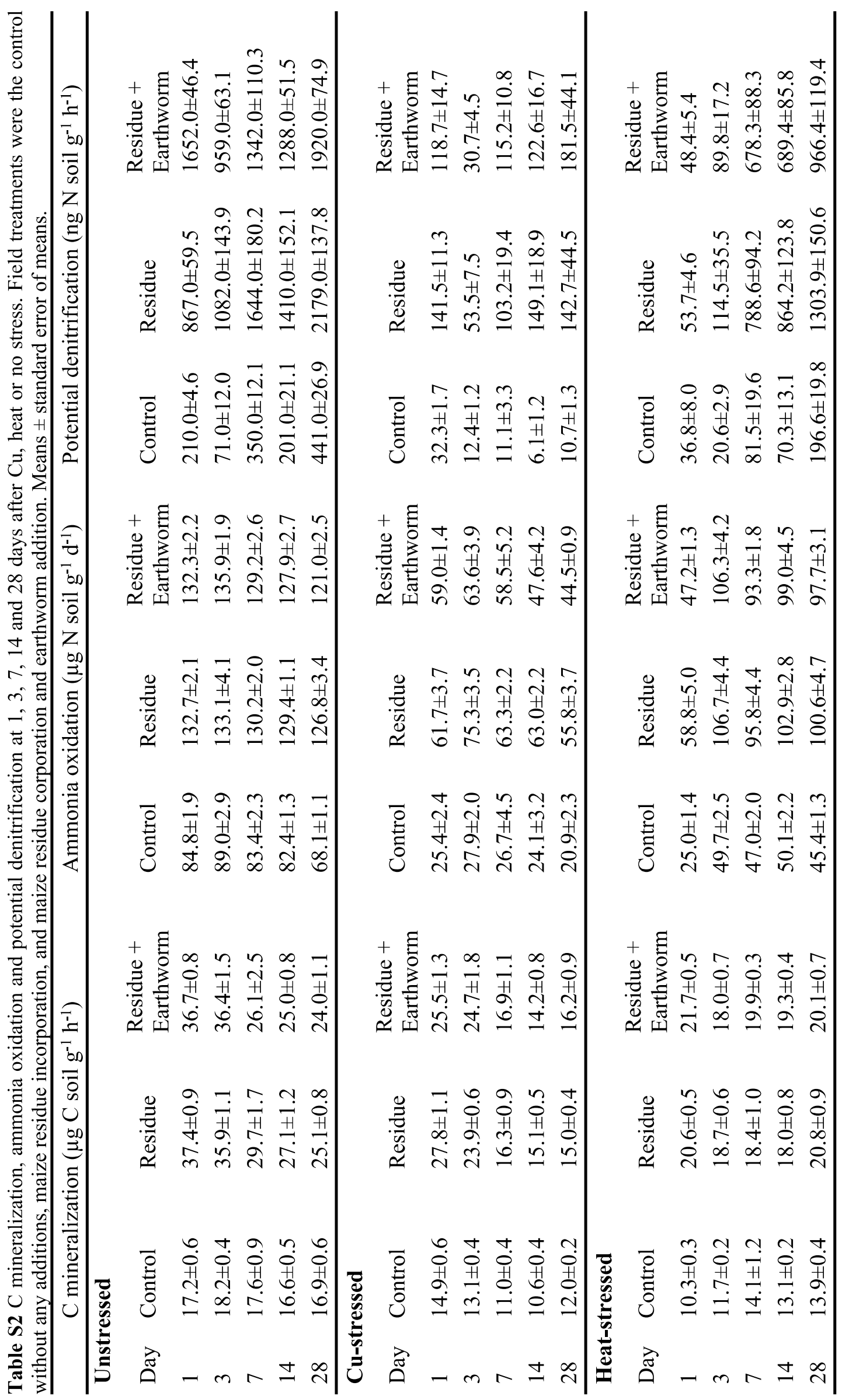




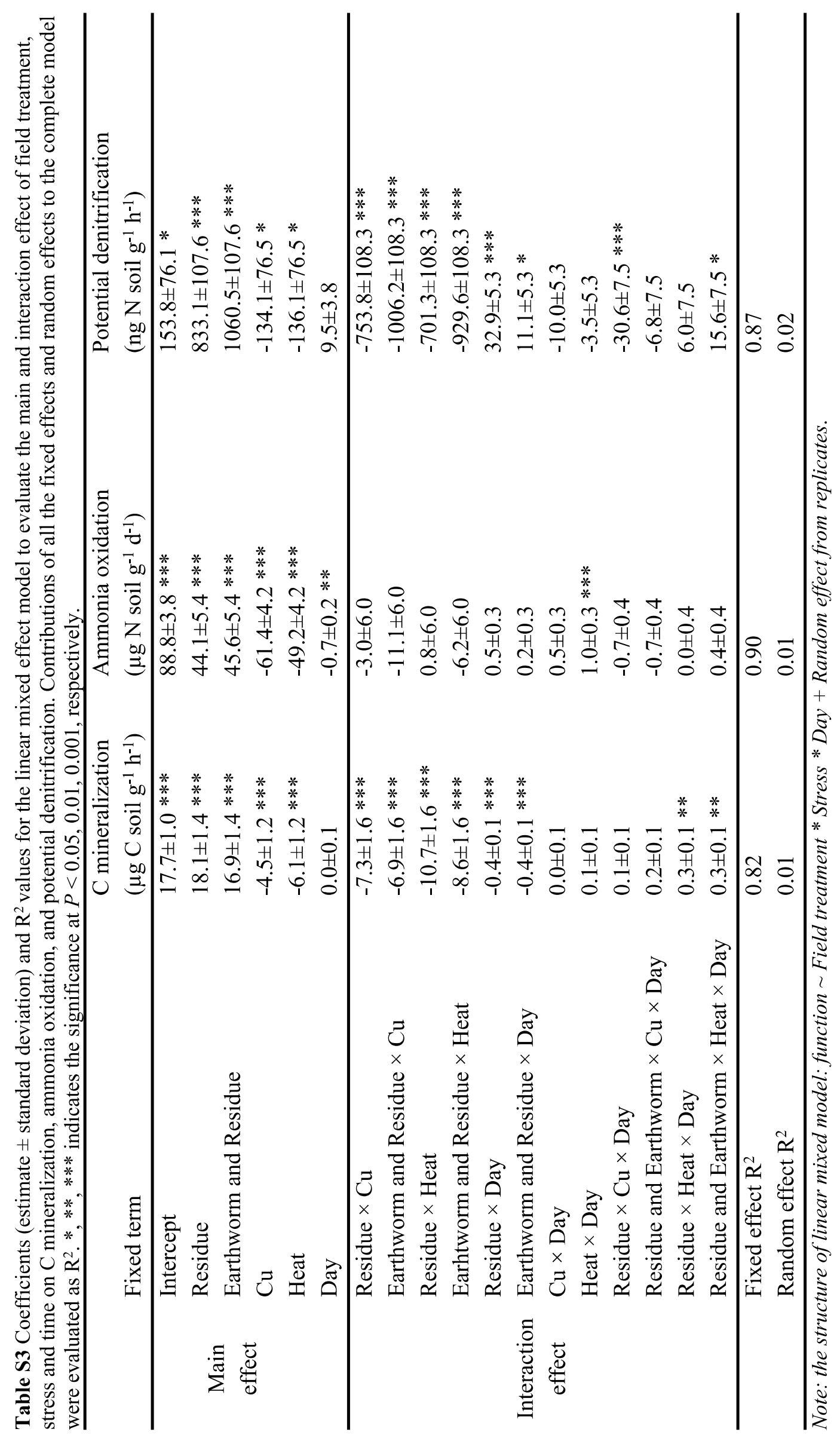

